\title{
Socioeconomic benefits of conserving Iran's water resources through modifying agricultural practices and water management strategies
}

\author{
Fatemeh Karandish
}

Received: 24 June 2020/Revised: 22 November 2020/Accepted: 2 February 2021/Published online: 23 March 2021

\begin{abstract}
Sustainable development requires modifying the current consumption pattern of natural resources. This study investigates efficient tactics for reducing the unsustainability and inefficiency of human's food-related blue water consumption alongside improving national environmental and socioeconomic status. As a case study for Iran, 15 alternative management scenarios (AMS) were defined compared to the current on-farm management, and their effects were assessed on a monthly scale. Based on the results, 45.5 billion $\mathrm{m}^{3} \mathrm{y}^{-1}(\mathrm{BCM})$ blue water is consumed within the croplands, $78 \%$ and $34 \%$ of which are unsustainable and inefficient, respectively. AMCs reduces the unsustainable and inefficient blue water consumption by $2-17$ BCM and $2-13$ BCM, respectively. The combination of yield gap closure, drip irrigation, soil mulching, and deficit irrigation has the largest effect on blue water saving; it releases or changes the status of monthly blue water scarcity in 11 provinces; increases field-employees by $132 \%$, food security by $9 \%$, international food-export by $87 \%$, and gross domestic production by $54 \%$. However, it doesn't fully address blue water overconsumption in the summer period; hence, further measures are needed to reduce blue water scarcity to the sustainable level in these environmental hotspots.
\end{abstract}

Keywords Blue water scarcity - Food security ·

Pressurized irrigation - Soil mulching .

Water saving irrigation - Yield gap closure

\section{INTRODUCTION}

Agriculture is the biggest freshwater user in the world and has the largest contribution of $92 \%$ in global blue water consumption (Hoekstra et al. 2012). Continuing the current pattern of agricultural water consumption threats the sustainability of future food security due to water shortage challenges (Steffen et al. 2015; Fitton et al. 2019). Reducing the vulnerability of sustainable crop production to water shortage is, thus, becoming a global concern (Jägermeyr et al. 2015). Hence, many researchers tried to find out pathways to increase food security under water scarcity status.

The opportunity of enhancing crop's yield, named yield gap closure (YGC), is one of the promising solutions which received large attention by many researchers (e.g., Phalan et al. 2011; Pretty et al 2011; Mueller et al. 2012; Garnett et al. 2013; Davis et al. 2017; Rosa et al. 2018). YGC is achieved through irrigation or agricultural practices and technology improvement. Expanding irrigated lands without overshooting the sustainable blue water availability is only possible in $25 \%$ of the global croplands (Rosa et al. 2020). Such expansion may provide $37 \%$ more calories, enough to feed 2.8 billion people, at the cost of 408 billion $\mathrm{m}^{3}$ year $^{-1}$ extra blue water consumption ( $48 \%$ more than the current condition) (Rosa et al. 2018). Nevertheless, replacing all rainfed lands with irrigated ones require 1130 billion $\mathrm{m}^{3} \mathrm{y}^{-1}$ additional blue water which is not available in many countries, and therefore, it may result in further unsustainable blue water consumption (Davis et al. 2017), mainly through overexploiting groundwater or fossil water abstraction (Nouri et al. 2019). Hence it is advised to improve crop's yield through methods which don't entail extra blue water consumption (Davis et al. 2017). Improving technologies and agricultural practices or modifying crops traits are among such methods (Ali and Talukder 2008; Chukalla et al. 2015; Jägermeyr et al. 2015; Rosa et al. 2018). For instance, YGC could be achieved through a transition toward drip/sprinkler irrigation (Jägermeyr et al. 2015), shifting cropping dates, modifying 
tillage practices, improving crop's traits or genetic (e.g., Ali and Talukder 2008; Sinclair and Rufty 2012; Chukalla et al. 2015; Karandish et al. 2017; Darzi-Naftchali and Karandish 2019), and improving nutrient applications or effectively controlling pests, diseases, and weeds in the croplands (Mueller et al. 2012; Sinclair and Rufty 2012). However, the effectiveness of these practices is sitespecific and need to be investigated from place to place.

Lessening agricultural blue water consumption is the other solution to this concern; it can reduce blue water scarcity and, consequently, increases food security. In this regard, earlier researchers proposed various methods to reduce applied water at the field scale including efficient irrigation techniques such as drip/sprinkler irrigation (Postel et al. 2001; Nouri et al. 2019), precision, and ondemand irrigation techniques (Greenwood et al. 2010), water saving irrigation strategies such as deficit irrigation (Chai et al. 2016; Karandish 2016), partial-root-zone drying (Karandish and Šimůnek 2018, 2019), and supplemental irrigation (Chukalla et al. 2015), soil mulching for reducing non-productive water demand (Chukalla et al. 2015; Pi et al. 2017; Nouri et al. 2019), conservation tillage practices (Liu et al. 2013) or soil organic amendments application (Miller and Naeth 2019) for improving soil's water holding capacity and properties, crop diversification (Lin 2011) and rotation (EIP-AGRI 2016) for enhancing the resilience of crop production to water shortage, cultivating more drought-tolerant crop cultivars to reduce the risk of production loss under water stresses $(\mathrm{Hu}$ and Xiong 2014), or reducing croplands under water intensive crops (Chouchane et al. 2020; Karandish et al. 2020). The effect of these practices may also vary from place to place, and from crop to crop, and therefore, this requires to be investigated locally.

In this research, we improve upon previous studies by evaluating the individual or simultaneous effects of YGC and improving agricultural and water management practices on alleviating water scarcity. We did our assessment at the national scale in contrast to the other studies that mainly focused on the field-scale consequences. We built our comparative assessment based on the water footprint concept (Hoekstra et al. 2011). Fifteen alternative management scenarios were defined compared to the base case (i.e., the current condition), and their consequences were assessed in terms of their effects on inefficient and unsustainable blue WF, and blue water scarcity index (BWS). While some researchers tried to quantify further blue water requirement under their proposed management scenarios (Chukalla et al. 2015; Davis et al. 2017; Rosa et al. 2018; Nouri et al. 2019), they rarely address the impacts of these scenarios on the efficiency and sustainably of blue WF. In addition, we did our BWS evaluations on a monthly scale in contrast to other studies that did on an annual basis (Vörösmarty et al. 2000; Oki et al. 2001). The annual assessment may provide an underestimation of environmental flow requirements (EFR) violation since it ignores intra-annual variabilities. We also did our monthly BWS assessment at the province scale to reveal the spatial variations as well.

We also improved upon earlier studies by assessing the socioeconomic consequences beside the environmental ones. We quantified the effects of implementing the best defined scenario on the number of farm-employees, provincial food security, the fraction of international food export, and gross domestic production. While such analyses may increase the acceptability of the proposed strategies, it is almost ignored in earlier studies that focused on water-related issues.

\section{MATERIALS AND METHODS}

\section{Main definition and assumptions}

We built our study on the basis of the WF assessment (Hoekstra et al. 2011). WF is a multi-dimensional indicator of water consumption which quantifies an appropriation of water resources along entire value chains (Hoekstra et al. 2011). It comprises of three main components: green, blue, and gray WFs (Hoekstra 2019; Hoekstra et al. 2011). We assessed Iran's agricultural WF and formulated the response options based on three indices: unsustainable EF, inefficient WF, and BWS. Following earlier researches (Hoekstra et al. 2011; Madani and Khatami 2015; Mekonnen and Hoekstra 2012, 2016; Hoekstra 2019), the standard definitions of the terms and relevant assumptions used in this study are summarized in Table 1.

\section{Study area}

This research was carried as a case study for Iran (Fig. 1), which is the second-largest country in the MENA region, and its per capita blue water availability dropped from 6350 in 1960, to 1553 in 2020. Based on the De Martonne climate classification method and using the meteorological data reported for 1985-2015, Iran is classified into five climatic zones including hyper-arid, arid, semi-arid, humid, and dry sub-humid (Fig. 1a). In 1960, 33\% of the renewable blue water was withdrawn for human consumption purposes and was consumed in the agricultural, domestic, and industrial sectors. Along with a $268 \%$ increase in population, this ratio reached $68 \%$ in 2020. Agriculture is the biggest freshwater user in Iran (AQUASTAT 2020). Since 1970, and along with implementing national policies for achieving self-sufficiency in food production, the irrigated croplands and consequently, blue water consumption in agriculture 
Table 1 Main definitions of the terms applied in the current research for the agricultural sector

\begin{tabular}{|c|c|c|c|}
\hline Term & Symbology & Definition and assumptions & Source of definition \\
\hline Water withdrawal & Agricultural WW & $\begin{array}{l}\text { Total freshwater input, supplied from surface or } \\
\text { groundwater, into the agriculture }\end{array}$ & Madani and Khatami (2015) \\
\hline Water consumption & Agricultural WC & $\begin{array}{l}\text { The portion of agricultural water withdrawal that has } \\
\text { become unavailable for reuse due to evaporative } \\
\text { losses, incorporation into the agricultural products, or } \\
\text { transfer to another catchment or sea }\end{array}$ & Madani and Khatami (2015) \\
\hline Water footprint & WF & $\begin{array}{l}\text { A multi-dimensional indicator of water consumption } \\
\text { which quantifies an appropriation of water resources } \\
\text { along entire value chains. It has three components } \\
\text { including green, blue, and gray WFs. We quantified } \\
\text { green and blue WF components in our assessment }\end{array}$ & $\begin{array}{l}\text { Hoekstra et al. (2011), Hoekstra } \\
\text { (2019) }\end{array}$ \\
\hline Green WF & $W F_{\text {green }}$ & $\begin{array}{l}\text { Evapotranspiration of rainwater; volume of rainwater } \\
\text { consumed for crop production during its lifecycle. It } \\
\text { is quantified by dividing green ET by crop yield. We } \\
\text { used AquaCrop-simulated yield and ET for } \\
\text { quantifying green WFs }\end{array}$ & $\begin{array}{l}\text { Hoekstra et al. (2011), Madani and } \\
\text { Khatami (2015), Hoekstra } \\
\text { (2019) }\end{array}$ \\
\hline Blue WF & $W F_{\text {blue }}$ & $\begin{array}{l}\text { evapotranspiration from surface or groundwater applied } \\
\text { through irrigation; volume of freshwater, supplied } \\
\text { from surface or groundwater, consumed for crop } \\
\text { production. We used AquaCrop-simulated yield and } \\
\text { ET for quantifying blue WFs }\end{array}$ & $\begin{array}{l}\text { Hoekstra et al. (2011), Madani and } \\
\text { Khatami (2015), Hoekstra } \\
\text { (2019) }\end{array}$ \\
\hline Blue water availability & Blue WA & $\begin{array}{l}\text { Natural runoff minus environmental flow requirement } \\
\text { (EFR). EFR is estimated based on Richter et al. } \\
\text { (2012), as a constant fraction of natural runoff }\end{array}$ & Hoekstra et al. (2011) \\
\hline WF benchmark & WF benchmark & $\begin{array}{l}\text { Minimum attainable WF in the location and time that } \\
\text { the considered crop is grown. We obtained the } \\
\text { climate-specific benchmark levels for the considered } \\
\text { crops from Karandish et al. (2018) }\end{array}$ & \\
\hline Inefficient blue WF & IE.WF $F_{\text {blue }}$ & $\begin{array}{l}\text { Inefficient blue water consumption occurs when the } \\
\text { crop's water footprint goes beyond its benchmark } \\
\text { level }\end{array}$ & Hoekstra et al. (2011) \\
\hline Unsustainable blue WF & $U S . W F_{\text {blue }}$ & blue WF minus blue water availability & Hoekstra et al. (2011) \\
\hline Blue water scarcity & BWS & $\begin{array}{l}\text { It is an indicator of water scarcity which compares } \\
\text { actual blue WF with the sustainable one. Different } \\
\text { BWS classes are defined by Mekonnen and Hoekstra } \\
\text { (2016), which are summarized in Table } 3\end{array}$ & Mekonnen and Hoekstra (2016) \\
\hline Attainable yield & $Y_{\text {att }}$ & $\begin{array}{l}\text { The best yield achieved through skillful se of the best } \\
\text { available technology under a given climate condition. } \\
\text { Here, we quantified attainable yield per crop per } \\
\text { climatic region. While differentiating between } \\
\text { attainable rainfed and irrigated yield, our focus in the } \\
\text { current study is on irrigated crops. maximum } \\
\text { attainable yields were determined based on long-term } \\
\text { local statistics }\end{array}$ & FAO and DWFI (2015) \\
\hline Actual Yield & $Y_{\text {act }}$ & $\begin{array}{l}\text { It reflects the current stage of soil and climate, average } \\
\text { skill of the farmers, and their average use of } \\
\text { technology. Actual yields are reported by local } \\
\text { organizations }\end{array}$ & FAO and DWFI (2015) \\
\hline Yield gap & YG & $\begin{array}{l}\text { Yield gap is defined as different between two levels of } \\
\text { yield and therefore, different yield gaps could be } \\
\text { defied (FAO and DWFI 2015). Here, and following } \\
\text { earlier researchers, we defined yield gap as the } \\
\text { different between attainable yield and actual yield. } \\
\text { This yield gap could be removed with improving } \\
\text { technologies and agricultural practices. Yield gap } \\
\text { might be even larger if we quantify it is the difference } \\
\text { between theoretical or potential yield and actual yield }\end{array}$ & FAO and DWFI (2015) \\
\hline
\end{tabular}



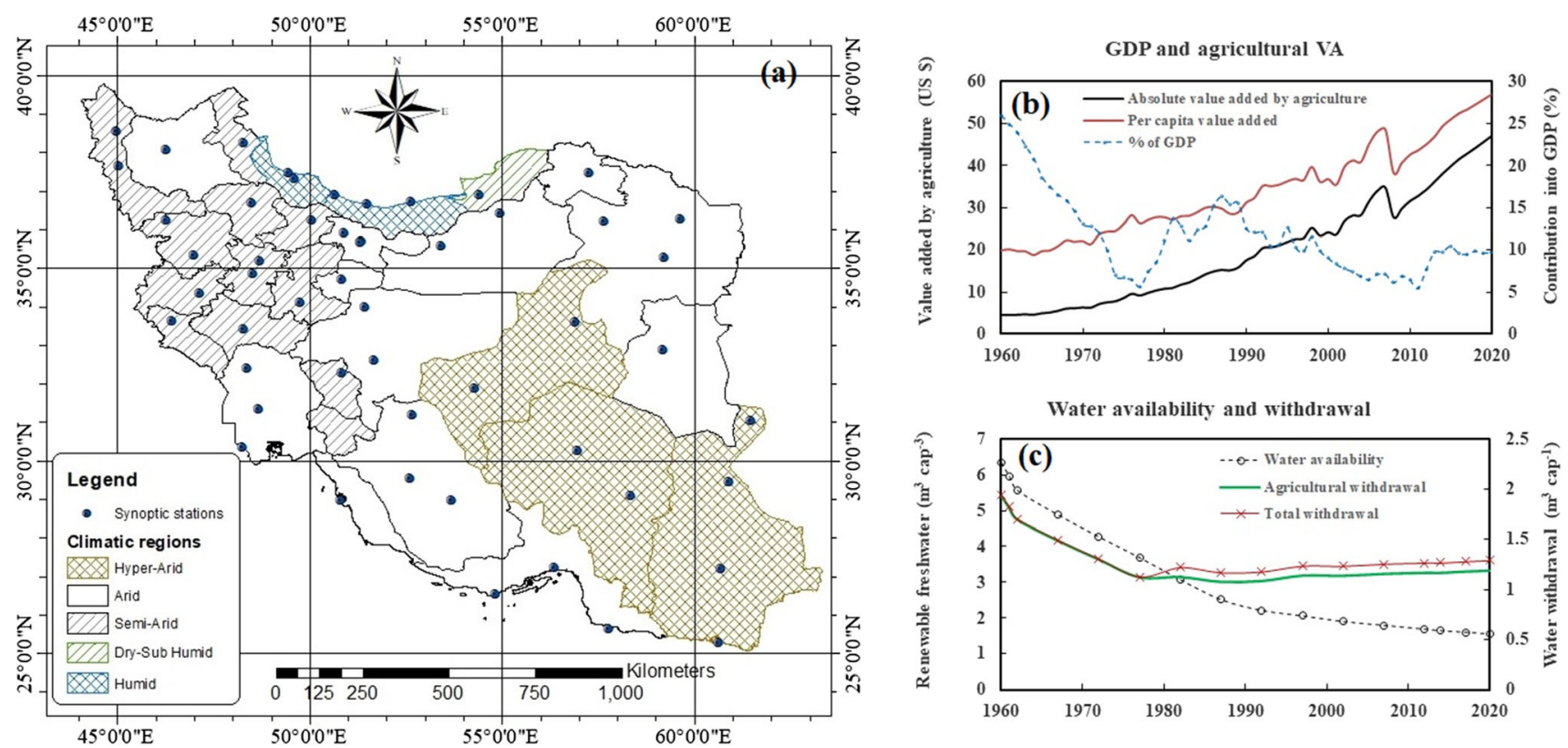

Fig. 1 The location of the study area (a), the temporal variation of gross domestic production (GDP) and agricultural value added (VA) (b), and per capita renewable freshwater resources and withdrawal (c) over the period 1960-2020

considerably increased (Madani 2014). Nevertheless, only $5-16 \%$ of Iran's gross domestic production (GDP) was supplied from the agriculture during 1979-2020 (Fig. 1b; UN 2020; WorldBank 2020), although having a contribution of $92 \%$ in gross blue water withdrawal, and $97 \%$ in net blue water abstraction (Fig. 1c; Karandish and Hoekstra 2017). Low added value obtained per drop of water consumption well indicates the low water productivity in agriculture which is also confirmed by previous researchers (Karandish and Hoekstra 2017; Nazari et al. 2018).

In this research, the status of the unsustainability and inefficiency of blue water consumed by 27 major crops grown in Iran were assessed either for the current condition or for the scenarios introduced in Sect. 2.3. These crops were classified into 8 crop categories: cereals, root and tubers, sugar crops, pulses, nuts, oil crops, vegetables, and fruits. The study period covers 10 years during 2005-2015. The 10-year average contribution of different crop categories into the national production and harvested area is summarized in Table 2 for five climatic zones of Iran; all numbers are in percentage $(\%)$. While having a contribution of $76 \%$ in total harvested area, cereals contribute $40 \%$ in national production, which indicates their relatively lower yields. Arid and semi-arid regions have the most contribution in total cereals production.

\section{Estimating WFs of crop production}

All calculations were done per crop, per province and per year over the period 2005-2015. Crops blue and green WFs were, respectively, estimated by dividing crop's seasonal green and blue water consumption by crop's yield. The green and blue water consumptions were estimated on a daily basis by distinguishing crop's total evapotranspiration (ET) into the green and blue fractions. Crop's ET was simulated by using the AquaCrop model (Steduto et al. 2009). The model simulates soil water balance components on a daily scale. The simulated components were then used to calculate green and blue water consumption following the procedure introduced by Hoekstra (2019). Seasonal green/blue water consumptions were then calculated by aggregating the daily values over the crop's growing cycle.

Total green or blue water consumed within a specific province per month was then estimated by the following equations:

$$
\begin{aligned}
& \left(\mathrm{WF}_{\text {green }}\right)_{\mathrm{p}, \mathrm{m}}=\sum_{i=1}^{n}\left(\mathrm{U} \cdot \mathrm{WF}_{\text {green }}\right)_{\mathrm{i}, \mathrm{p}, \mathrm{m}} \times \mathrm{TP}_{\mathrm{i}, \mathrm{p}} \\
& \left(\mathrm{WF}_{\text {blue }}\right)_{\mathrm{p}, \mathrm{m}}=\sum_{i=1}^{n}\left(\mathrm{U} \cdot \mathrm{WF}_{\text {blue }}\right)_{\mathrm{i}, \mathrm{p}, \mathrm{m}} \times \mathrm{TP}_{\mathrm{i}, \mathrm{p}}
\end{aligned}
$$

where, $\left(\mathrm{WF}_{\text {green }}\right)_{\mathrm{p}, \mathrm{m}}$ and $\left(\mathrm{WF}_{\text {blue }}\right)_{\mathrm{p} . \mathrm{m}}$ are absolute green and blue WFs $\left(\mathrm{m}^{3}\right.$ month $\left.^{-1}\right)$ consumed by all crops grown in province $p$ and in month $m$, $\mathbf{U} \cdot \mathrm{WF}_{\text {green }}$ and $\mathrm{U}_{\mathrm{W}} \mathrm{WF}_{\text {blue }}$ are unit green and blue WFs $\left(\mathrm{m}^{3} \mathrm{t}^{-1}\right), T P_{i, p, m}$ is total production $\left(t\right.$ year $\left.^{-1}\right)$ of crop $i$ in province $p$, and $\mathrm{n}$ is the number of the crops.

All required data for the study period of 2005-2015 were collected per crop per province per year. Daily weather data were obtained from observations at 52 
Table 2 The 10-year average contribution of different crop categories in national harvested area and production in different climatic zones over the study period 2005-2015. i.e., all numbers are in percentage (\%)

\begin{tabular}{|c|c|c|c|c|c|c|c|}
\hline \multirow[t]{2}{*}{ Parameter } & \multirow[t]{2}{*}{ Crop categories } & \multicolumn{5}{|c|}{ Climatic zones } & \multirow[t]{2}{*}{ Iran } \\
\hline & & Hyper-arid & Arid & Semi-arid & Dry sub-humid & Humid & \\
\hline \multirow[t]{8}{*}{ Contribution in harvested area (\%) } & Cereals & 51.4 & 75.6 & 80.1 & 75.1 & 66.3 & 75.8 \\
\hline & Root and Tuber & 1.3 & 1.6 & 1.5 & 1.7 & 0.7 & 1.5 \\
\hline & Sugar crops & 0.4 & 2.8 & 0.6 & 0 & 0 & 1.5 \\
\hline & Pulses & 1.5 & 5.2 & 10.1 & 0.8 & 3.7 & 6.7 \\
\hline & Nuts & 27.1 & 4.8 & 2.7 & 0 & 4.3 & 4.7 \\
\hline & Oil crops & 0.5 & 0.8 & 0.9 & 20.5 & 13 & 2.5 \\
\hline & Vegetables & 1.6 & 3.1 & 0.8 & 1.2 & 0.9 & 1.9 \\
\hline & Fruits & 16.1 & 6 & 3.2 & 0.6 & 11.1 & 5.3 \\
\hline \multirow[t]{8}{*}{ Contribution in total production (\%) } & Cereals & 30.1 & 32.2 & 51.9 & 61.8 & 50 & 39.6 \\
\hline & Root and Tuber & 5 & 6.9 & 13 & 9.8 & 1.5 & 8.1 \\
\hline & Sugar crops & 2.1 & 28.4 & 7.5 & 0 & 0.1 & 18.6 \\
\hline & Pulses & 0.4 & 0.9 & 3.1 & 0.2 & 0.7 & 1.4 \\
\hline & Nuts & 14.5 & 1.3 & 1.8 & 0 & 0.9 & 2 \\
\hline & Oil crops & 0.2 & 0.4 & 0.6 & 15.1 & 4 & 1.2 \\
\hline & Vegetables & 7.1 & 18.3 & 8.1 & 10 & 2.5 & 13.7 \\
\hline & Fruits & 40.6 & 11.6 & 13.9 & 3 & 40.3 & 15.3 \\
\hline
\end{tabular}

synoptic stations spread out over the country. Reference evapotranspiration (ETo) was then calculated based on the FAO-Penman-Monteith equation (Allen et al. 1998). Soil physical properties were extracted from Batjes (2012), and its ware parameters were obtained from the manual of the AquaCrop model (Steduto et al. 2012). Farming information, including crop's harvest area (ha), and yield $\left(t \mathrm{ha}^{-1}\right)$, planting/harvesting dates, and farming practices were obtained from Iran's Ministry of Agriculture Jihad (IMAJ 2019).

\section{Unsustainable/inefficient blue water consumption}

Unsustainability. Per province per month, blue water scarcity $\left(\mathrm{BWS}_{\mathrm{p}, \mathrm{m}}\right)$ was determined by Eq. 3 (Hoekstra et al. 2011).

$\mathrm{BWS}_{\mathrm{p}, \mathrm{m}}=\frac{(\text { blue WC })_{\mathrm{p}, \mathrm{m}}}{\left(\mathrm{BW}_{\text {available }}\right)_{\mathrm{p}, \mathrm{m}}}=\frac{\text { (blue water consumption })_{\mathrm{p}, \mathrm{m}}}{\mathrm{NR}_{\mathrm{p}, \mathrm{m}}-\mathrm{EFR}_{\mathrm{p}, \mathrm{m}}}$

where blue WC is total blue water consumption $\left(\mathrm{m}^{3}\right.$ $\left.\mathrm{month}^{-1}\right), \quad \mathrm{BW}_{\text {available }}$ is blue water availability $\left(\mathrm{m}^{3}\right.$ month $\left.{ }^{-1}\right), N R$ is natural runoff $\left(\mathrm{m}^{3}\right.$ month $\left.^{-1}\right), E F R$ is environmental flow requirement $\left(\mathrm{m}^{3}\right.$ month $\left.^{-1}\right), p$ denotes province, and $m$ denotes month. Data on monthly $N R$ per province were obtained from Iran's Water Resource Management Company (IWRMC 2020). Following Richter et al. (2012), EFRs were assumed as $80 \%$ of natural runoffs. The BWS classes are defined in Table 3 (Mekonnen and Hoekstra 2016).

A month/place with a BWS $>1$ is called an environmental hotspot, in which part of the blue water consumption which is beyond blue water availability, is unsuitable. In the hotspot, the unsustainable fraction of the blue WF of a specific crop will be determined based on the ratio of the blue WF of that crop to total blue water consumed in the considered hotspot:

$$
\begin{aligned}
\left(\mathrm{US} . \mathrm{WF}_{\text {blue }}\right)_{\mathrm{c}, \mathrm{p}, \mathrm{m}}= & \frac{\left(\mathrm{WF}_{\text {blue }}\right)_{\mathrm{c}, \mathrm{p}, \mathrm{m}}}{\left(\mathrm{WF}_{\text {blue }}\right)_{\mathrm{p}, \mathrm{m}}} \\
& \times\left(\left(\mathrm{WF}_{\text {blue }}\right)_{\mathrm{p}, \mathrm{m}}-\left(\mathrm{BW}_{\text {available }}\right)_{\mathrm{p}, \mathrm{m}}\right)
\end{aligned}
$$

where, $\left(\mathrm{US} . \mathrm{WF}_{\text {blue }}\right)_{\mathrm{c}, \mathrm{p}, \mathrm{m}}$ is the unsustainable blue water footprint for crop $c$ in province $p$ and month $m,\left(\mathrm{WF}_{\text {blue }}\right)_{\mathrm{p}, \mathrm{m}}$ and $\left(\mathrm{WF}_{\text {blue }}\right)_{c, p, m}$ are, respectively, total and the considered crop's blue WF in province $p$ and month $m$, and $\left(\mathrm{BW}_{\text {available }}\right)_{\mathrm{p}, \mathrm{m}}$ is local blue water availability in province $p$ and month $m$.

Inefficiency. Crop's blue water consumption is inefficient when it goes beyond its benchmark levels. We obtained the climate-specific benchmark levels for the considered crops from Karandish et al. (2018). Per crop, per province, and per month, the inefficient blue WF was then determined as the difference between actual and benchmark WFs of the considered crops. 
Table 3 Different blue water scarcity (BWS) classes defined by Mekonnen and Hoekstra (2016). A hotspot is a month/place in which blue water consumption exceeds blue water availability

\begin{tabular}{llll}
\hline Range of BWS & Scarcity status & Descriptions & Hotspot? \\
\hline$<1$ & No scarcity & Blue water consumption is less than the available blue water & No \\
$1-1.5$ & Moderate scarcity & Blue water consumption exceeded the available blue water & Yes \\
$1.5-2$ & Significant scarcity & Blue water consumption exceeded the available blue water & Yes \\
$>2$ & Sever scarcity & Blue water consumption exceeded the available blue water & Yes \\
\hline
\end{tabular}

\section{Scenario assessment and consequences}

As summarized in Table 4, a total of 15 alternative management scenarios compared to the current (field/irrigation) management were defined by considering the individual or combined effects of the following measures:

- Yield gap closure

- Replacing current irrigation systems with drip irrigation

- Soil mulching with organic matters

- Applying deficit irrigation by reducing irrigation water depth by $15 \%$

In yield gap closure scenario, the climate-specific attainable yields for a specific crop and in a specific climatic zone was assumed to be the upper quantile (top 25\%) of yield statistics reported for that crop in the considered zone over the study period 2005-2015. Yield gap was then estimated as the difference between actual and attainable yields.

In Drip irrigation scenario, the existing irrigation system is assumed to be replaced by drip irrigation system except for rice, wheat and barley, for which applying drip irrigation is not technically feasible in the study area.

Soil mulching was assumed to be applied within all croplands unless rice fields, since rice is irrigated by basin method; hence, soil mulching is not relevant. In deficit irrigation scenario, crops were assumed to receive $15 \%$ less blue water in each irrigation event during their entire growing periods. The other 11 combined scenarios were defined as different combinations of these four measures.

The environmental consequences of all scenarios were then assessed in terms of their effects on blue water consumption and saving, unsustainable/inefficient fraction of blue WFs, and BWS. These consequences were compared

Table 4 The 15 alternative management scenarios defined compared to the current on-farm management in the study area

\begin{tabular}{|c|c|c|c|c|c|}
\hline Scenario no.* & Name of scenario & $\begin{array}{l}\text { Drip irrigation } \\
\text { (DRIP) }\end{array}$ & $\begin{array}{l}\text { Soil mulching } \\
\text { (MULCH) }\end{array}$ & $\begin{array}{l}\text { Deficit irrigation } \\
\text { (DI15\%) }\end{array}$ & $\begin{array}{l}\text { Yield gap closure } \\
\text { (YGC) }\end{array}$ \\
\hline 1 & DR & $*$ & & & \\
\hline 2 & MU & & $*$ & & \\
\hline 3 & DI & & & $*$ & \\
\hline 4 & YGC & & & & $*$ \\
\hline 5 & DR.MU & $*$ & $*$ & & \\
\hline 6 & DR.DI & $*$ & & $*$ & \\
\hline 7 & DR.YGC & $*$ & & & $*$ \\
\hline 8 & DR.MU.DI & $*$ & $*$ & $*$ & \\
\hline 9 & DR.MU.YGC & $*$ & $*$ & & $*$ \\
\hline 10 & DR.DI.YGC & $*$ & & $*$ & * \\
\hline 11 & MU.DI & & $*$ & $*$ & \\
\hline 12 & MU.YGC & & $*$ & & $*$ \\
\hline 13 & MU.DI.YGC & & $*$ & $*$ & $*$ \\
\hline 14 & DI.YGC & & & $*$ & $*$ \\
\hline 15 & DR.MU.DI.YGC & $*$ & $*$ & $*$ & $*$ \\
\hline
\end{tabular}

*Drip irrigation is applied for all crops, except for wheat, barley, and rice, for which this irrigation technique is not technically feasible. Soil mulching was assumed to be applied within all croplands unless rice fields, since rice is irrigated by basin method; hence, soil mulching is not relevant. In deficit irrigation, crops were assumed to receive $15 \%$ less blue water in each irrigation event during their entire growing periods. Yield gaps were calculated per crop per climatic zone while differentiating between the irrigated and rainfed crops 
with the relevant values under the current condition, which is called the base case in this research. Among 15 defined scenario, the best scenario was then selected as one which has the largest effect on reducing unsustainable and inefficient blue WF and BWS. We name it as "the best scenario" afterward.

Finally, the socioeconomic consequences were assessed for the best alternative management scenario in terms of its effects on the daily number farm-employees (NFE), provincial food security (FSp), the fraction of international food export (IFE), and gross domestic production (GDP). Per crop per province, Iran's Ministry of Agriculture Jihad (IMAJ) defined standard numbers for NFE per unit of crop production (cap t ${ }^{-1}$ ) (IMAJ 2019). These values were used to estimate NFE for the base case and for the best scenario. Per province, FSp is defined by dividing local food production by local food demand. Local food demand is estimated by multiplying per capita food demand by local population. International food export is estimated as surplus production beyond national demand. The IFE was then calculated by dividing total export by total production.
GDP for the current condition was extracted from Statistical Center of Iran (SCI 2016). For the best scenario, the value added by the additional production was added to the current GDP.

\section{RESULTS}

\section{Unsustainability/inefficiency in blue WF under current condition}

Annually, 182-3181 million $\mathrm{m}^{3}$ year $^{-1}$ of blue water is consumed unsustainably within the hotspots $($ BWS $>1$ ) (Fig. 2a). Monthly unsustainable blue water consumption occurs in 23 provinces over the period April-November; accounted for $0.92-712$ million $\mathrm{m}^{3}$ month $^{-1}$, which comprises $12-89 \%$ of monthly blue water consumptions in these provinces. April and October, has the less contribution in annual US. WF $F_{\text {blue, }}$ while July has the most one. Three provinces of Fars, Khuzestan, and Razavi-Khorasan, locating within the arid zone with less blue water

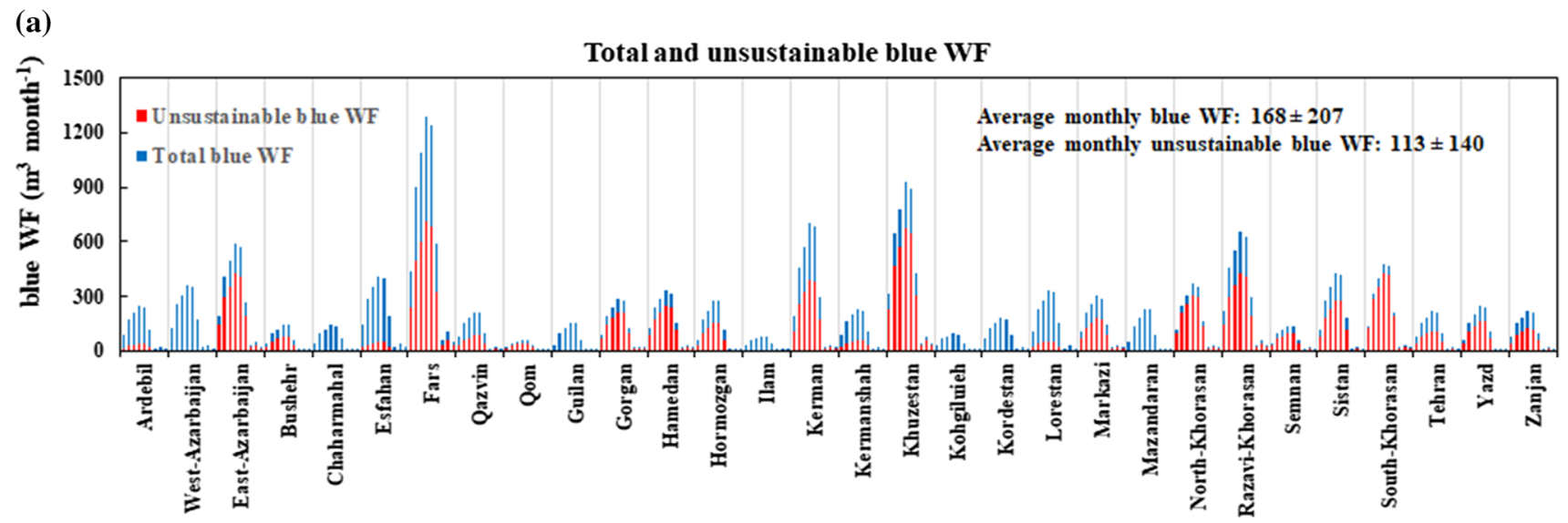

(b)

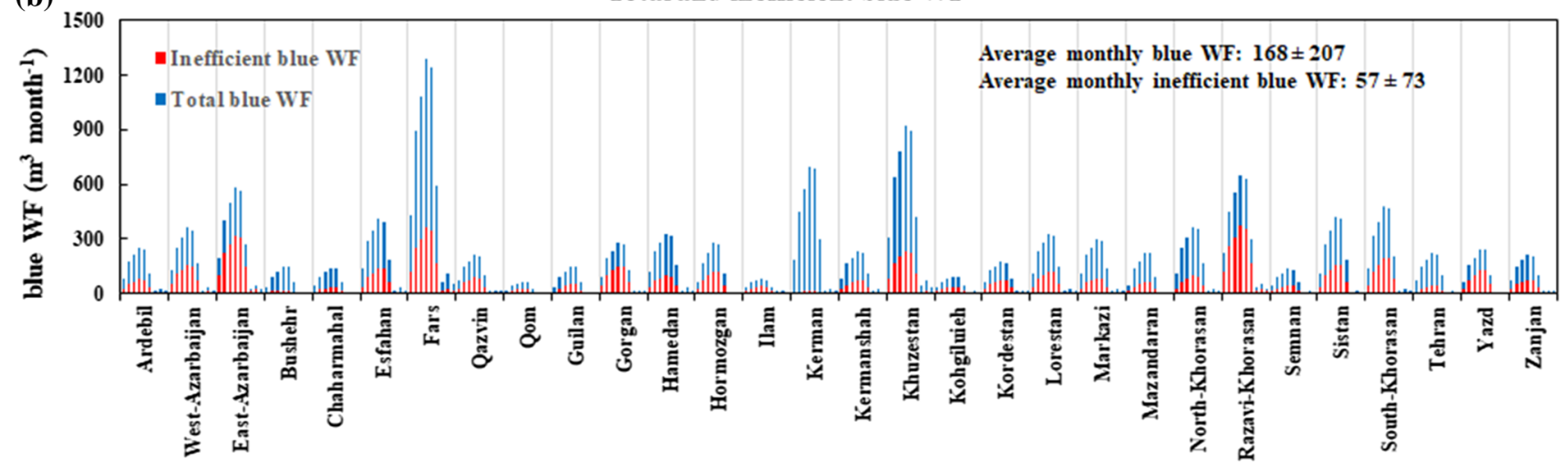

Fig. 2 The 10-year average of monthly unsustainable (a) and inefficient (b) blue water consumption in different provinces of Iran over the study period 2005-2015. For each province, 9 months are included as vertical bars starting from April and ending at December. The vertical grids differentiate between different provinces 
(a)

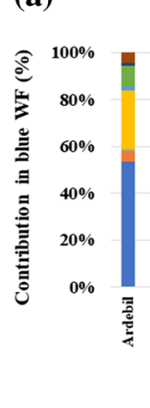

Contribution of different crop categories in provincial unsustainable blue WF

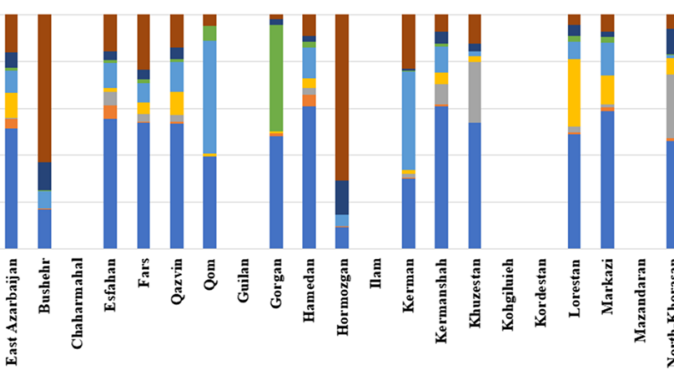

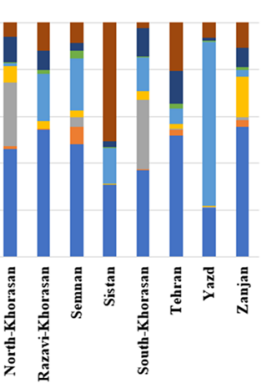

(c)

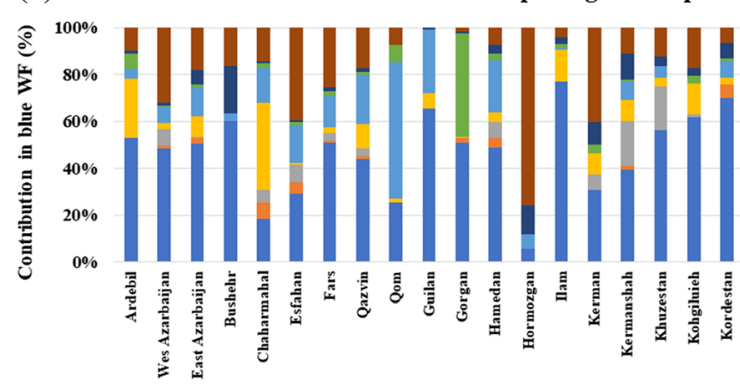

Contribution of different crop categories in provincial inefficient blue WF

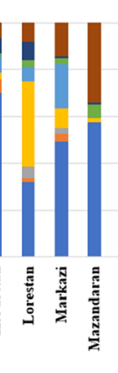

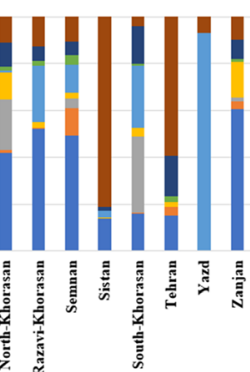

- Fruits

- Veget ables -Oil crops

$\because$ Nuts

$\because$ Pulses

- Sugar crops - Cereals
- Root\&Tubers

(b)

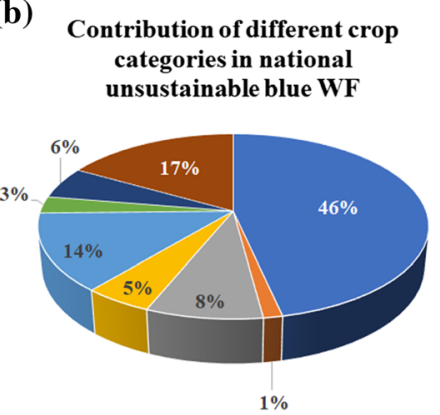

(d) Contribution of different crop

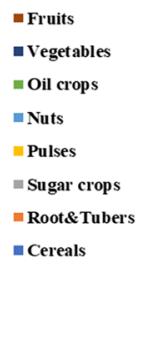
categories in nationalinefficient blue WF

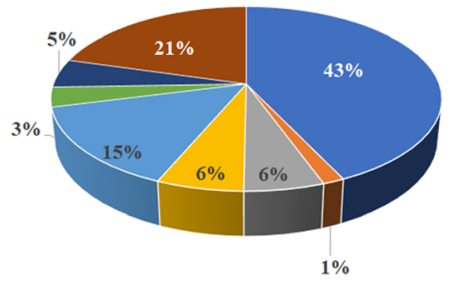

Fig. 3 The 10-year average of the contribution of different crop categories in provincial and national unsustainable (a, b) and inefficient (c, d) blue WFs over the period 2005-2015

availability, have the highest monthly US. FF $_{\text {blue. In Seven }}$ provinces of Chaharmahal\&Bakhtirari, Ilam, Kohgiluyeh and Boyer-Ahmad, Kordestan, and West-Azarbaijan (in the semi-arid zone), and Gilan and Mazandaran (in the humid zone), blue water is fully consumed sustainably in the agricultural sector (i.e., $\mathrm{US} \mathrm{WF}_{\text {blue }}=0$ and $\mathrm{BWS}<1$ ).

On an annual scale, 67-1661 million $\mathrm{m}^{3}$ year $^{-1}$ of blue water is consumed inefficiently in different provinces (Fig. 2b). Provincial monthly inefficient blue water consumption varies in the range of $0.1-373$ million $\mathrm{m}^{3}$ month $^{-1}$, which comprises $3-57 \%$ of monthly blue water consumption in different provinces. December and July have the lowest and the highest monthly IE. $\mathrm{WF}_{\text {blue }}$, respectively. Furthermore, Kerman province has the lowest monthly IE. $\mathrm{WF}_{\text {blue, }}$ and three provinces of Razavi-Khorasan, Fars, and East-Azarbaijan (all in the arid zone) has the highest ones.

Figure 3 shows the 10-year average of the contribution of different crop categories in provincial and national US.WF blue (Fig. 3a, b) and IE. WF $_{\text {blue }}$ (Fig. 3c, d) overt the study period. Of 35.5 billion $\mathrm{m}^{3}$ year ${ }^{-1}$ US. $\mathrm{WF}_{\text {blue }}$ consumed within the entire irrigated croplands in the study area, $46 \%, 17 \%$, and $14 \%$ is consumed by cereals, fruits, and nuts, respectively, while the other $23 \%$ is consumed by the other five crop categories. Cereals also had the highest contribution of $43 \%$ (6.7 billion $\mathrm{m}^{3}$ year ${ }^{-1}$ ) in the national IE. $\mathrm{WF}_{\text {blue }}\left(15.5\right.$ billion $\mathrm{m}^{3}$ year $\left.{ }^{-1}\right)$, followed by fruits $(21 \%)$, and nuts (15\%). Such a dominant contributions of these crop categories are also observed at the province scale.

\section{Unsustainability/inefficiency in blue WF under proposed scenarios}

Figure 4 shows the monthly blue water availability and consumptions under the current condition and 15 alternative management scenarios and the contribution of different crop categories in blue water saving. Compared to the current condition, all scenarios have the potential of blue water saving, and the highest savings always occur in August (accounted for 2-19 billion $\mathrm{m}^{3}$ month $^{-1}$ ). Replacing current irrigation systems with drip irrigation when feasible (i.e., DR scenario) comes with the lowest blue water saving of 4.8 billion $\mathrm{m}^{3}$ year $^{-1}$ (a $5 \%$ saving compared to the current condition). In contrast, combining yield gap closure with drip irrigation, mulching, and deficit irrigation at the rate of $15 \%$ (i.e., the DR.MU.DI.YGC scenario), will save a total of 38.3 billion $\mathrm{m}^{3}$ year ${ }^{-1}$ blue water (a $42 \%$ saving compared to the current condition). In this scenario, the largest saving occurs within the cereals field.

Figure 5 shows the degree to which these savings can reduce provincial US.WF $\mathrm{Wlue}_{\text {blue }}$ and IE. $\mathrm{WF}_{\text {blue }}$. Except for a few cases, the lowest and the highest reduction in US. $\mathrm{WF}_{\text {blue }}$ and IE. $\mathrm{WF}_{\text {blue }}$ occurs under the DR and the DR.MU.DI.YGC scenarios, respectively. Based on the ensemble averages of all scenarios, provincial US. $\mathrm{WF}_{\text {blue }}$ 


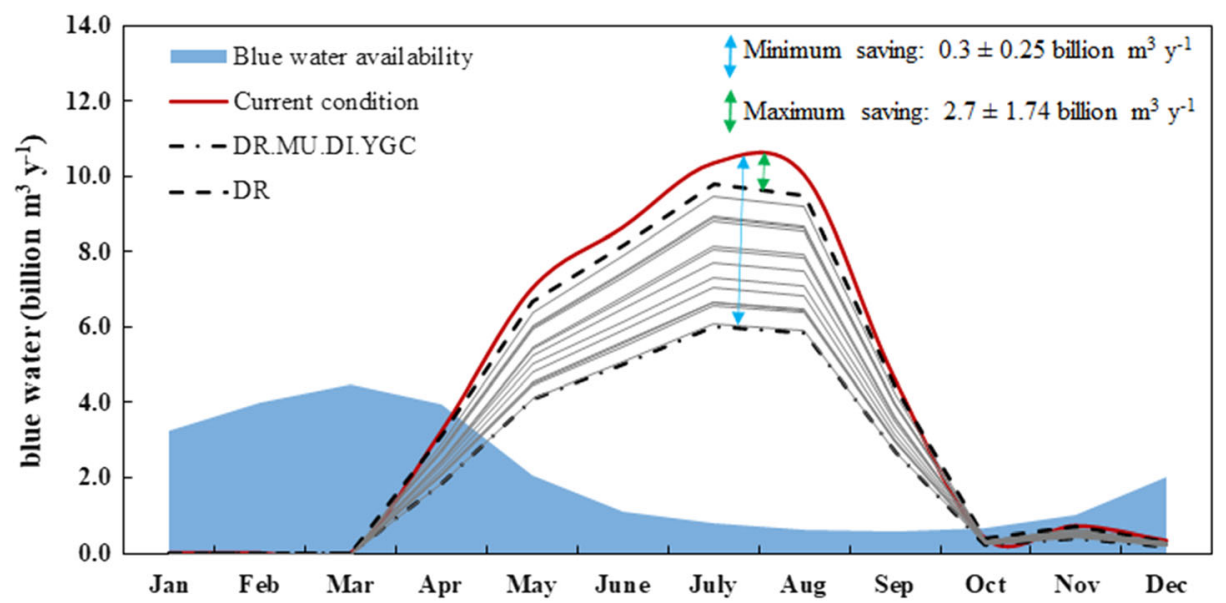

Order of scenario-curves from top to down:

\begin{tabular}{c|c} 
Scenario number & Scenario number \\
\hline 1 & DR \\
3 & DI \\
6 & DR.DI \\
2 & MU \\
5 & DR.MU \\
11 & MU.DI \\
8 & DR.MU.DI \\
4 & YGC \\
7 & DR.YGC \\
14 & DI.YGC \\
10 & DR.DI.YGC \\
12 & MU.YG \\
9 & DR.MU.YGC \\
13 & MU.DR.YGC \\
15 & DR.MU.DI.YGC
\end{tabular}

Fig. 4 The 10-year average of monthly blue water consumption and availability under current and 15 proposed alternative scenarios over the study period 2005-2015. The scenarios with the lowest and highest blue water saving compared to base case (i.e., the current condition over the period 2005-2015) were highlighted in the figure, which were, respectively, drip irrigation scenario (DR) and the combination of yield gap closure (YGC), drip irrigation (DR), mulching (MU), and deficit irrigation applied at the rate of $15 \%$ reduction in crop's blue water demand (DI). Table in right shows the order of curves for different management scenarios from top to down

will decrease from $96 \pm 45$ million $\mathrm{m}^{3}$ year $^{-1}$ (in Qom province) to $1337 \pm 556$ million $\mathrm{m}^{3}$ year $^{-1}$ (in Fars province) (Fig. 5b); and the provincial IF. WF blue will decrease from $32 \pm 11$ million $\mathrm{m}^{3}$ year $^{-1}$ (in Kerman province) to $931 \pm 321$ million $\mathrm{m}^{3}$ year $^{-1}$ (in Fars province) (Fig. 5c).

Table 5 shows the degree to which $\mathrm{US}^{-\mathrm{WF}_{\text {blue }} \text { and }}$ IE. $\mathrm{WF}_{\text {blue }}$ can be reduced for different crop categories. Based on the ensemble averages of all scenarios, the largest reduction in US. $\mathrm{WF}_{\text {blue }}$ and IE. $\mathrm{WF}_{\text {blue }}$ will occurs within the cereals lands, accounted for $4.6 \pm 2.2$ billion $\mathrm{m}^{3}$ year $^{-1}$ and $4.1 \pm 1.7$ billion $^{3}$ year $^{-1}$, respectively. This result attributes to the fact that cereals are dominant either in the national harvested area or in national crop production. The lowest reduction, however, will occur within the croplands under root

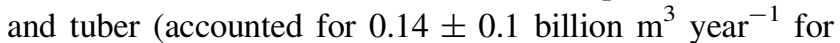

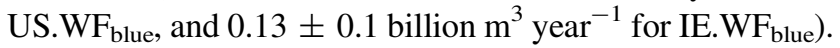
This result is caused by the fact that potato, as the only crop in root and tuber category, has the lowest blue WF, and so does the lowest unsustainable and inefficient fractions.

\section{Blue water scarcity alleviation}

Figure 6 shows monthly BWS under the current condition and the DR.MU.DI.YGC scenario (i.e., the best scenario out of 15 defined scenarios which results in the highest reduction in $U S . W_{\text {blue }}$ and $\mathrm{IE}_{\mathrm{W}}\left(\mathrm{WF}_{\text {blue }}\right)$. For the current condition, overconsumption of blue water occurs during the April-November period at the cost of violating EFRs (BWS > 1), and possibly, using the fossil water resources. In April, moderate to significant BWS occurs in roughly half of the country, while the next half absents from BWS. In May, most of the provinces experience a sever BWS. During the July-September period, sever BWS occurs for almost all provinces since the growing periods of many crops fall within this period in the study area. However, BWS in Autumn (October and November) is low and occurs only in a few provinces.

Reduced blue water consumption under the DR.MU.DI.YGC scenario will change the status of BWS in many provinces and months. Unless for a few provinces, the overall blue water consumption remains below blue water availability $(\mathrm{BWS}<1)$ during the October-December period, and in April. In May, the status of BWS will change from 'sever' to 'moderate'/ 'significant' in ten provinces, and will change to 'not-scarce' in four provinces. However, the status of BWS remains unchanged in the majority of the provinces over the period June-September.

While the DR.MU.DI.YGC scenario can alleviate BWS to some extent, it is still insufficient to address the problem of blue water overconsumption in the agricultural sector. Despite of the promising outcomes, there will be many provinces and months with BWS $>1$; hence, other measures should be explored in addition to those introduced in this research to solve the problem.

\section{Socio-economic consequences under the best measure}

The socioeconomic consequences of implementing the best water saving scenario among 15 defined ones (the DR.MU.DI.YGC scenario) are estimated and results are summarized in Table 6. Under the DR.MU.DI.YGC scenario, annual crop production will increase by 17.8 million $\mathrm{t}_{\text {year }}{ }^{-1}$ due to yield gap closure $(87.6 \%$ compared to the current condition, Fig. 7), and blue water consumption will decrease due to applying drip irrigation, mulching, and 

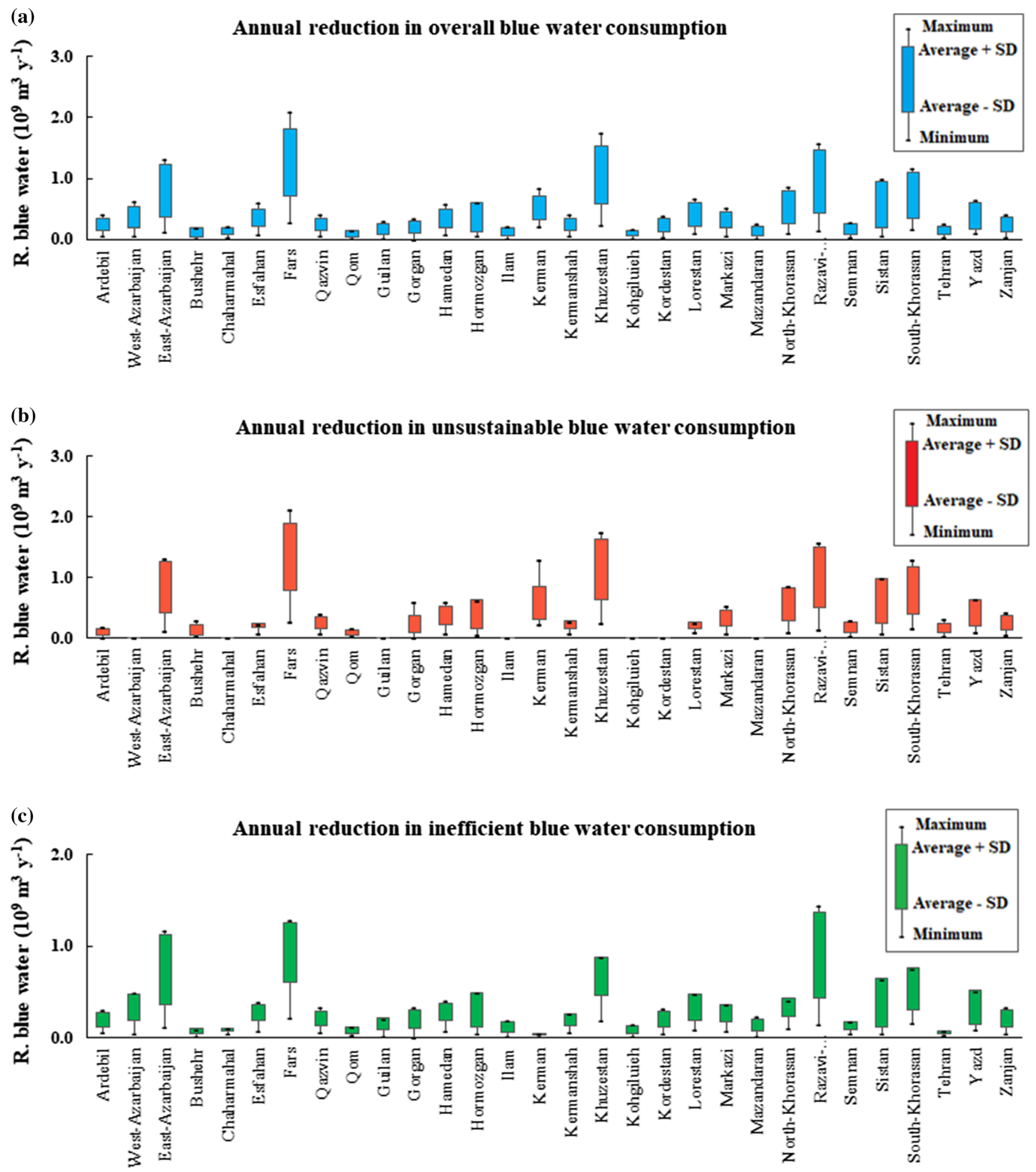

Fig. 5 Average, minimum, and maximum reduction in annual overall (a), inefficient (b), and unsustainable (c) blue water consumption under 15 alternative management scenarios compared to the base case. Except for Gorgan, Mazandaran, and Hormozgan provinces, the lowest and the highest reductions in the overall, unsustainable, and inefficient blue water consumptions occur under the DR and the DR.MU.DI.YGC scenarios, respectively. For Goragn, Mazandaran, and Hormozgan provinces, the lowest and highest reductions occur under the MU and the DR.MU.DI.YGC scenarios, respectively. i.e., DR denotes drip irrigation scenario, MU denotes mulching scenario, and the DR.MU.DI.YGC denotes the scenario in which yield gap closure is combined with drip irrigation, mulching, and deficit irrigation 
Table 5 Ensemble average, minimum, maximum, and standard deviation (SD) of the potential reductions in unsustainable (US.WF $\mathrm{F}_{\text {blue }}$ ) and inefficient (IE. WF $_{\text {blue }}$ ) blue WFs under the defined scenarios for different crop categories in the study area over the period 2005-2015

\begin{tabular}{|c|c|c|c|c|c|c|c|c|}
\hline \multirow[t]{2}{*}{ Crop categories } & \multicolumn{4}{|c|}{ Reduction in US. $\mathrm{WF}_{\text {blue }}$ (billion $\mathrm{m}^{3}$ year $^{-1}$ ) } & \multicolumn{4}{|c|}{ Reduction in IE.Wfblue (billion $\mathrm{m}^{3}$ year $^{-1}$ ) } \\
\hline & Ensemble average & Minimum & Maximum & SD & Ensemble average & Minimum & Maximum & SD \\
\hline Cereals & 4.64 & 7.89 & 0.27 & 2.18 & 4.04 & 6.00 & 0.03 & 1.65 \\
\hline Root and Tuber & 0.14 & 0.23 & 0.04 & 0.05 & 0.13 & 0.19 & 0.03 & 0.05 \\
\hline Sugar crops & 0.76 & 1.21 & 0.30 & 0.30 & 0.65 & 0.85 & 0.32 & 0.18 \\
\hline Pulses & 0.73 & 1.11 & 0.28 & 0.39 & 0.64 & 0.89 & 0.27 & 0.30 \\
\hline Nuts & 1.98 & 3.14 & 0.59 & 0.98 & 1.56 & 2.25 & 0.48 & 0.77 \\
\hline Oil crops & 0.26 & 0.41 & 0.12 & 0.09 & 0.24 & 0.36 & 0.09 & 0.08 \\
\hline Vegetables & 0.56 & 0.85 & 0.23 & 0.29 & 0.50 & 0.72 & 0.21 & 0.24 \\
\hline Fruits & 1.36 & 2.32 & 0.34 & 0.77 & 1.04 & 1.63 & 0.27 & 0.61 \\
\hline
\end{tabular}

deficit irrigation. These outcomes result in a considerable reduction in crop's unit WFs $\left(\mathrm{m}^{3} \mathrm{t}^{-1}\right)$. Hence, national GDP will increase by $54 \%$, from 21 billion US\$ year ${ }^{-1}$ to 32.4 billion US\$ year ${ }^{-1}$, and provincial GDP will increase by $380 \pm 415$ million US\$ year ${ }^{-1}$ (Table 6). As a consequence, provincial food security will increase by $9 \%$ due to the increased contributions of different provinces in crop production. Hence, the dependency on international food import will decrease by $5 \%$, and the contribution to international food export will increase by $87 \%$ (from 22 to $42 \%$ ). The DR.MU.DI.YGC scenario has also the potential of reducing unemployment rates since the number of farmemployees will increase by $132 \%$, from 9.1 thousand people days $^{-1}$ to 21.1 thousand people days ${ }^{-1}$.

\section{DISCUSSION}

In this study, we tried to map out the WF scheme of the agricultural sector in Iran, and propose pathways for alleviating blue water scarcity in the country. This study includes various limitations and uncertainties. First, the AquaCrop model was used to estimated ET and yield while using the default parameters in some cases. When data are available, calibrating and validating the model against field conditions will provide more accurate results. Second, the use of data with different spatial resolutions may cause some inconsistencies in the given results. In addition, the results may be sensitive to different environmental conditions; for instance, the results may change when hydrologically differentiating between the dry and wet periods (Zhuo et al. 2016), or when more detailed equations are applied to estimate EFRs (Karandish et al., in press). Hence, their impacts can be assessed in further investigations.

Our monthly WF assessment indicates that over the period 2005-2015, Iran consumed $0.17 \pm 0.21$ million $^{3}$ month $^{-1}$ of its blue water resources for crop production,
$113 \pm 40$ million $\mathrm{m}^{3}$ month $^{-1}$ of which was consumed unsustainably within hotspots (Fig. 2a), and $57 \pm 73$ million $\mathrm{m}^{3}$ month ${ }^{-1}$ consumed inefficiently (Fig. 2b). The spatial variation of the unsustainable and inefficient blue WFs is partly due to the spatial variation of crops' ET, which depends on seasonal and inter-annual climatic status change (Khazaei et al. 2019). Iran has a large geographic diversity of hydro-climatic regimes due to having a spatial difference of $16.65^{\circ} \mathrm{C}$ for its annual average temperature, and $1107 \mathrm{~mm} \mathrm{y}^{-1}$ for its annual precipitation (Madani 2014; Moshir Panahi et al. 2020). The site-specific behavior of unsustainable and inefficient blue WFs in Iran is also caused by the regional differences of cropping patterns.

The unsustainable and inefficient water consumption in Iran's agricultural sector roots in different reasons. First, the country is suffering from a natural water scarcity. Over the past decades, Iran became warmer, its annual precipitation and surface runoff experienced a decreasing trend, and faced with severe droughts in 1990 and 2008 (Karandish et al. 2017; Moshir-Panahi et al. 2020). For instance, annual precipitation in the western basins, which are the backbone of crop production in Iran (Karandish et al. 2017), decreased by $65 \mathrm{~mm} \mathrm{year}^{-1}$ over the period 1986-2016 (Moshir-Panahi et al. 2020). Continuing agriculture production under such condition entailed exacerbating unsustainable exploitation of the limited blue water resources. Recently, Moshir-Panahi et al. (2020) also reported that Iran's current evapotranspiration is beyond its sustainable level which could be maintained by only annual renewable water input.

Second, Iran's technical capacity is limited by different economic and political sanctions, which caused the lack of access to novel technologies, international scientific exchanges, and foreign investments. Hence, the lack of industrialized agriculture and using almost outdated farming technologies and practices is among the major causes of inefficient agriculture in Iran (Madani 2014; Madani et al. 2016). 


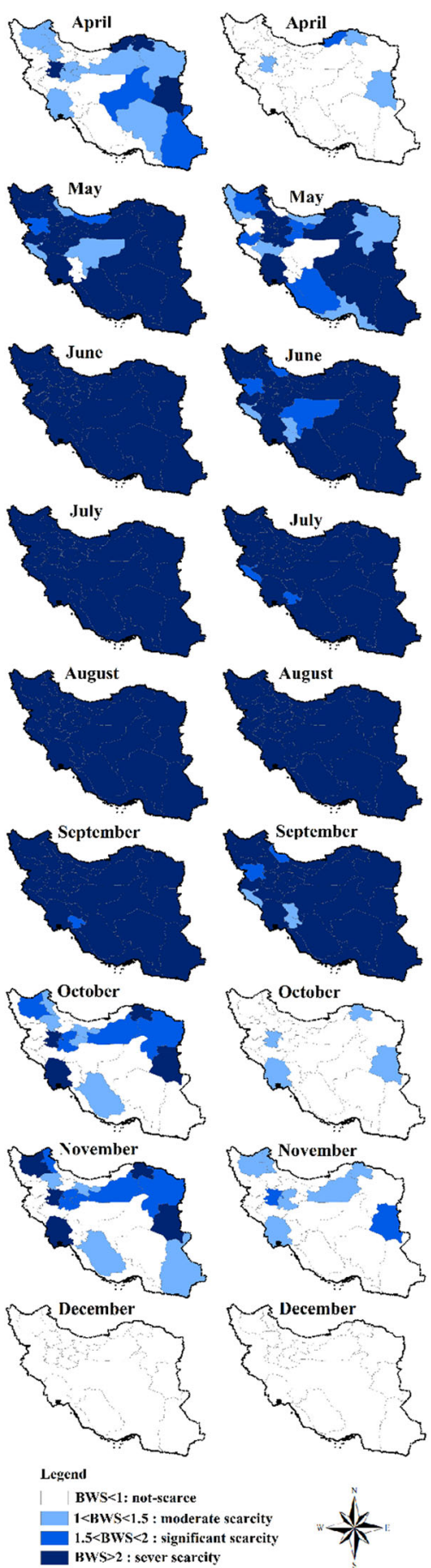

Fig. 6 Spatial distribution of monthly blue water scarcity (BWS) under the base case (i.e., the current condition over the period 2005-2015) (maps in the left hand), the scenario with maximum blue water saving (i.e., the combination of yield gap closure (YG), drip irrigation (DRIP), mulching (MULCH), and deficit irrigation applied at the rate of $15 \%$ reduction in crop's blue water demand (DI15\%)) (maps in the left hand)

Third, while climate variability, climate change, droughts, and sanctions exposed undeniable impacts on
Iran's water resources, its water challenges in the agricultural sector is mostly man-human-made.

Maghrebi et al. (2020) reported the insensitivity of irrigated crop productions to natural water availability changes in the water-scarce regions of Iran, which reveals that the historical development of the irrigated agriculture in Iran was not compatible with its blue water availability changes. Over the period 1981-2013, total irrigated production in Iran increased by 137\% (Maghrebi et al. 2020), while the local statistics show that total water shortage changes (including surface and groundwater) followed a decreasing trend of $16 \mathrm{~mm} \mathrm{y}^{-1}$ in this period, which implies a considerable decline in Iran's blue water availability (Moshir Panahi et al. 2020). On the other hand, a considerable part of irrigated farming expansions took place in the southern, eastern, and central parts of the country, with higher reliance on groundwater resources (Maghrebi et al. 2020). The expansion of irrigated croplands in Iran was motivated by the national food policy implemented in 1979 to achieve self-sufficiency in food production (Madani 2014; Karandish and Hoekstra 2017). The increased blue water demand was then fulfilled through an extensive building of artificial reservoirs (Madani 2014), overexploitation of groundwater resources (Mirzaei et al. 2019; Karandish et al. 2020), and implementation of inter-basin water transfer projects (Mirchi and Madani 2016; Karandish et al. 2021). Indeed, developing irrigated agriculture occurred at the cost of consuming the non-renewable blue water resources which have been supplied through building 127 dams with an overall storage capacity of about 35 billion $\mathrm{m}^{3}$ year $^{-1}$, and drilling more than 540000 wells across the country (Maghrebi et al. 2020). In other words, Iran's decision makers tried to solve Iran's water scarcity by increasing water supply through infrastructure development rather than doing strict water conservation efforts (Madani et al. 2016). Hence, the longterm continuation of overlooking the linkage between environment and development planning caused serious water problems which may last for generations (DarziNaftchali et al. 2020).

Our scenario assessment revealed that Iran's blue water scarcity could be moderated through modifying agricultural practices and water management. The combination of YGC with drip irrigation, mulching, and deficit irrigation (i.e., the DR.MU.DI.YGC scenario) has the largest water saving potential. In this scenario, YGC has the largest effect on reducing unsustainable and inefficient blue WFs. Earlier researchers also indicated the key role of yield improvement in reducing crop's WFs (Zhuo et al. 2014). While Rosa et al. (2018) indicated that Iran's yield gap could be closed through expanding irrigation infrastructures into the rainfed lands, we didn't focus on waterlimited yield gap in the current research. The main reason 
Table 6 Socioeconomic consequences of implementing the best water saving agricultural practices in the study area. i.e., the best scenario refers to the combination of fulfilling yield gap (YG), drip irrigation (DRIP), mulching (MULCH), and deficit irrigation applied at the rate of $15 \%$ reduction in crop's blue water demand (DI15\%)

\begin{tabular}{llll}
\hline Parameter & Base case & The best scenario & Average increase $(\%)$ \\
\hline Provincial GDP (million US\$ y ${ }^{-1}$ ) & $700 \pm 511$ & $1080 \pm 789$ & 54 \\
National GDP (million US\$ $\mathrm{y}^{-1}$ ) & 21002 & 32390 & 54 \\
Provincial FS (\%) & $53 \pm 18$ & $58 \pm 18$ & 9 \\
Contribution in international export (\%) & 22 & 42 & 87 \\
International import dependency (\%) & 2.7 & 2.6 & -5 \\
Number of employee per day (1000 people) & 9.1 & 21.1 & 132 \\
\hline
\end{tabular}

is that Rosa et al. (2018) carried out their BWS assessment on an annual scale and for the country as whole, which hides the intra-annual and intra-national variabilities in blue water availability and demands. Our finer spatial/ temporal resolution BWS assessment well reveals that the majority of the country experiences moderate to severe blue water scarcity over the period May-September. Hence, YGC through replacing rainfed lands with irrigated one should be done by caution and required further deeper assessments of the consequences before being implemented. Indeed, improving rainfed/irrigated crop's yield to the maximum climate-specific one, while keeping water consumption unchanged, should be of higher priority. Such yield benchmark levels may be achievable in Iran since a majority of the croplands are suffering from the lack of input managements, best available technologies and proper agricultural practices (Mueller et al. 2012; Rosa et al. 2020). However, further research is also required to assess the extent to which yield gap could be closed without increasing unsustainable and inefficient blue water consumption.

In addition to improving the environmental status, implementing the DR.MU.DI.YGC scenario will also improve the national socioeconomic status by decreasing unemployment rate and the dependency on international food import, and by increasing GDP, food security level, and the contribution to international export. Reduced unemployment rate and increased GDP will prosper the welfare of the inhabitants, particularly in the rural area. In addition, increased local food security will increase the resilience to the unexpected international shocks, such as market shocks or pandemic diseases. Nowadays, the power is going to be transferred from the large agricultural companies and global markets to the local actors (DuPuis and Goodman 2005; Burnett and Murphy 2014). Kinnunen et al. (2020) stated that localness of food systems is the main source of many narratives associated with sustainability. They indicated that closing crop's yield gap and reducing food losses are among two key drivers which promote the stability of eating local.
However, the current study considered the benefits of yield gap closure, drip irrigation, mulching, and deficit irrigation but not the cost. Practically, the beneficial effects of applying these measures might outweigh their costs. Hence, the costs of these measures for reducing BWS should be evaluated by using a marginal cost assessment like one carried out by Chukalla et al. (2017). In addition, the feasibility of applying these measures vary from crop to crop and place to place; therefore, further researches are required to evaluate the stability of the proposed solutions (Read et al. 2014).

Furthermore, our monthly BWS reveals that while the DR.MU.DI.YGC scenario has the potential of reducing the number of hotspots (i.e., place/month with BWS $>1$, Fig. 6), there are still many cases in which crop production takes place at the cost of violating EFRs. Nouri et al. (2019) also reported that a combination of soil mulching with drip irrigation couldn't fully address monthly blue water scarcity in the Upper Litani Basin. Our results show that EFR violations mainly occur during the dry periods, while there is no BWS over the wet period of DecemberMarch; when the natural runoff is far beyond the EFRs. Hence, a plausible solution to address water shortage in such hotspots is to store addition water in the artificial reservoirs during the wet periods, and to release them during the dry periods. Zhuo et al. (2019) demonstrated that water footprint cap in the dry periods, when crop's water demand is the most, could be raised when runoff variability is smoothed by constructing reservoirs along the river in the Yellow-River basin in China. Nouri et al. (2019) also emphasized on the positive role of artificial reservoir on reducing BWS during the dry periods. However, dam constructions may also have negative socioeconomic and environmental consequences. For instance, Zhuo et al. (2019) stated that when water storage in the wet periods goes beyond $20 \%$ of natural runoff, then the EFR wouldn't be met in this period, which results in off-season BWS. On the other hand, reservoirs themselves are considered as blue water consumers. The overall evaporated water from reservoirs surfaces equals to $25 \%$ of total blue 

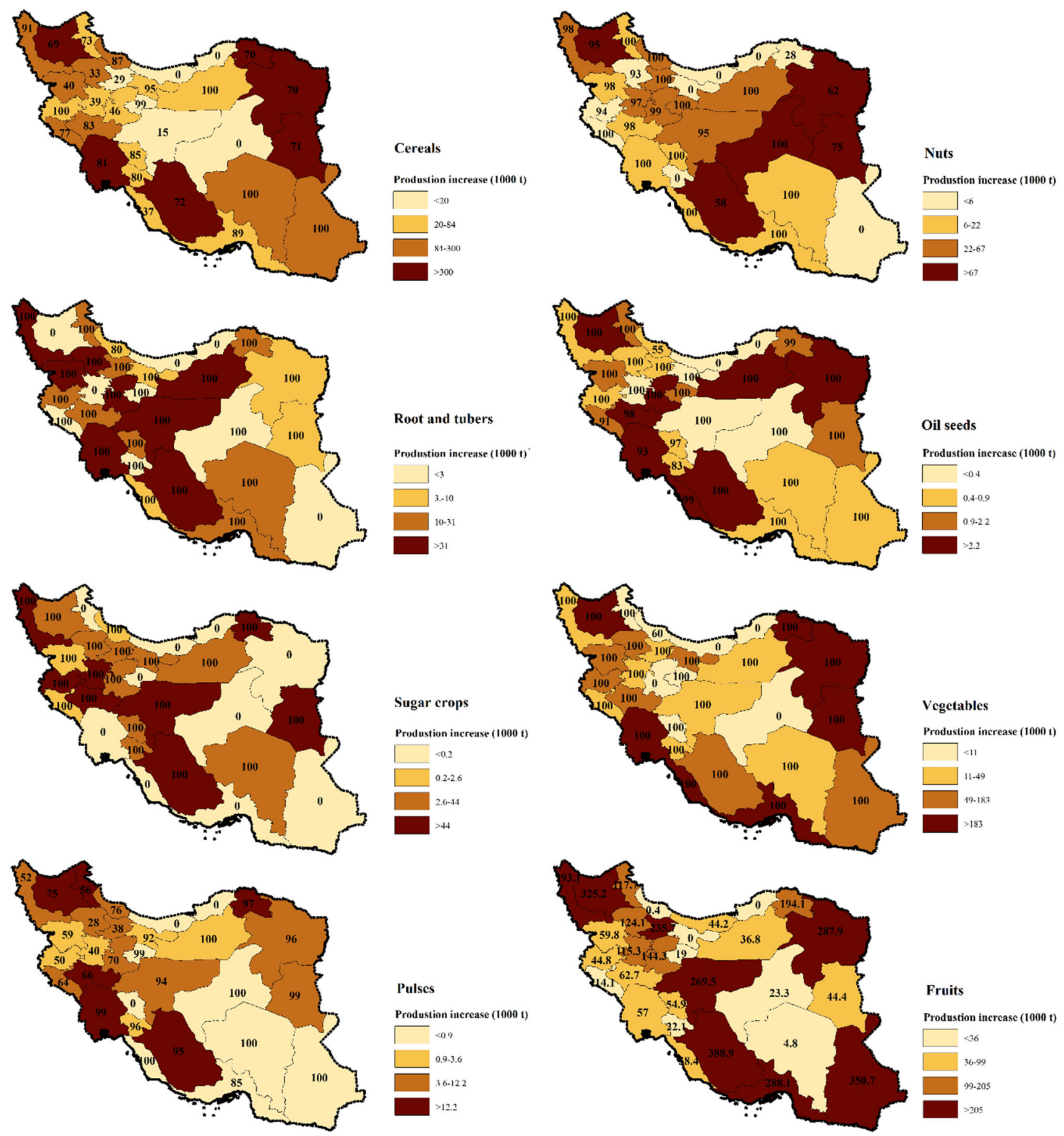

Fig. 7 The provincial gap between the actual and climate-specific attainable yield for different crop categories in the study area over the period 2005-2015. The numbers in the maps denotes the contribution of irrigated crops in total production gap

water annually consumed by irrigated agriculture/munici$\mathrm{pal} /$ industrial sectors in the world (Hogeboom et al. 2018; Mekonnen and Hoekstra 2012). Hence, this solution also requires further comprehensive assessments before being implemented.

\section{CONCLUSION}

Fulfilling the increasing food demand requires the sustainable and efficient use of finite water resources. This study assesses the possibilities for reducing unsustainability and 
inefficiency in crop's blue water consumption while preventing food security losses. The study was carried out as a case study for Iran, where the available water consumption pattern involves $78 \%$ and $34 \%$ unsustainability and inefficiency, respectively, resulting in moderate to severe blue water scarcity (BWS) in a large part of the country over the period April-November. Hence sustaining agriculture in this country requires substantial adjustments to current technologies and agricultural practices and water management. In this regard, blue water saving possibilities were assessed through defining 15 alternative management scenarios compared to the base case by considering the individual or combined effects of four major measures: yield gap closure, drip irrigation, soil mulching, and deficit irrigation. Results show that all scenarios have positive impacts on reducing unsustainability and inefficiency in blue water consumption nationwide, while combining all four mentioned measures, with a potential blue water saving of 19 million $\mathrm{m}^{3}$ year $^{-1}$, has the largest effect. Such a potential water saving reduces unsustainable and inefficient blue water consumption by $48 \%$ and $84 \%$, respectively; environmental deterioration is also expected to be lowered since this scenario has the potential of releasing monthly BWS or changing its status to the smoother levels in up to 11 provinces. Moreover, the socioeconomic condition may also improve along with an increase of $132 \%$ in the daily number of farm-employees, $9 \%$ in provincial food security, $87 \%$ in international food export contribution, and $54 \%$ in gross domestic production. While the findings of this study confirm that the sound and sensible agriculture through the defined scenarios have the potentials of contributing to food and water security with lower impacts on natural ecosystems, but by far they are not sufficient to fully address BWS in many provinces. Indeed, orienting the current food production system to a more sustainable trajectory requires exploring other measures such as conservation tillage, cultivating different crop cultivars, or modifying the cropping pattern. Besides, the findings of the current research show the potential of reducing BWS in the dry period by storing additional water in artificial reservoirs during not-scarce wet periods. However, dam constructions have their own consequences and need to be deeply investigated before implementation. If none of these measures have the potential of solving blue water overconsumption, then the harvested area under the irrigated crops should be reduced.

Acknowledgements This project has received funding from the European Research Council (ERC) under the European Union's Horizon 2020 research and innovation programme (Earth@1ternatives project, grant agreement No 834716).

Open Access This article is licensed under a Creative Commons Attribution 4.0 International License, which permits use, sharing, adaptation, distribution and reproduction in any medium or format, as long as you give appropriate credit to the original author(s) and the source, provide a link to the Creative Commons licence, and indicate if changes were made. The images or other third party material in this article are included in the article's Creative Commons licence, unless indicated otherwise in a credit line to the material. If material is not included in the article's Creative Commons licence and your intended use is not permitted by statutory regulation or exceeds the permitted use, you will need to obtain permission directly from the copyright holder. To view a copy of this licence, visit http://creativecommons. org/licenses/by/4.0/.

\section{REFERENCES}

Ali, M.H., and M.S.U. Talukder. 2008. Increasing water productivity in crop production-A synthesis. Agricultural Water Management 95: 1201-1213.

Allen, R.G., L.S. Pereira, D. Raes, and M. Smith. 1998. Crop Evapotranspiration: Guideline for Computing Crop Water Requirements, vol. 56. Rome: FAO.

AQUASTAT. 2020. FAO's Global Information System on Water and Agriculture. Rome, Italy. http://www.fao.org/aquastat/en/.

Batjes, N.H. 2012. ISRIC-WISE Global Data Set of Derived Soil Properties on a 5 by 5 Arc-Minutes Grid (Version 1.2); Report 2012/01; ISRIC World Soil Information: Wageningen, The Netherlands.

Burnett, K., and S. Murphy. 2014. What place for international trade in food sovereignty? The Journal of Peasant Studies 41: 1065-1084.

Chai, Q., Y. Gan, C. Zhao, H.-L. Xu, R.M. Waskom, Y. Niu, and K.H.M. Siddique. 2016. Regulated deficit irrigation for crop production under drought stress. A reiew. Agronomy for Sustainable Development 36: 3.

Chouchane, H., M.S. Krol, and A.Y. Hoekstra. 2020. Changing global cropping patterns to minimize national blue water scarcity. Earth System Sciences 24: 3015-3031. https://doi.org/10.5194/hess-243015-2020,2020.

Chukalla, A.D., M.S. Krol, and A.Y. Hoekstra. 2015. Green and blue water footprint reduction in irrigated agriculture: Effect of irrigation techniques, irrigation strategies and mulching. Hydrology and Earth System Sciences 19: 4877-4891.

Chukalla, A.D., M.S. Krol, and A.Y. Hoekstra. 2017. Marginal cost curves for water footprint reduction in irrigated agriculture: Guiding a cost-effective reduction of crop water consumption to a permit or benchmark level. Hydrology and Earth System Sciences 21: 3507-3524.

Darzi-Naftchali, A., M. Bagherian-Jelodar, F. Mashhadi-Kholerdi, and M. Abdi-Moftikolaei. 2020. Assessing socio-environmental sustainability at the level of irrigation and drainage network. Science of the Total Environment. https://doi.org/10.1016/j. scitotenv.2020.138927.

Darzi-Naftchali, A., and F. Karandish. 2019. Adapting rice production to climate change for sustainable blue water consumption: An economic and virtual water analysis. Theoretical and Applied Climatology. 135: 1-12.

Davis, K.F., M.C. Rulli, F. Garrassino, D. Chiarelli, A. Seveso, and P. D'Odorico. 2017. Water limits to closing yield gaps. AdWR 99: $67-75$.

DuPuis, E.M., and D. Goodman. 2005. Should we go "home" to eat?: Toward a reflexive politics of localism. Journal of Rural Studies 21: $359-371$.

EIP-AGRI. 2016. Water \& Agriculture: Adaptive Strategies at Farm Level. The agricultural European Innovation Partnership (EIPAGRI). Brussels, Belgium: European Commission. 
FAO and DWFI. 2015. Yield Gap Analysis of Field Crops: Methods and Case Studies. Rome, Italy: Food and Agriculture Organization of the United Nations.

Fitton, N., P. Alexander, N. Arnell, B. Bajzelj, K. Calvin, J. Doelman, J.S. Gerber, P. Havlik, et al. 2019. The vulnerabilities of agricultural land and food production to future water scarcity. Global Environmental Change 58: 101944.

Garnett, T., M.C. Appleby, A. Balmford, I.J. Bateman, T.G. Benton, P. Bloomer, B. Burlingame, M. Dawkins, et al. 2013. Sustainable intensification in agriculture: Premises and policies. Science 341: 33-34.

Greenwood, D.J., K. Zhang, H.W. Hilton, and A.J. Thompson. 2010. Opportunities for improving irrigation efficiency with quantitative models, soil water sensors and wireless technology. Journal of Agricultural Science 148: 1-16.

Hoekstra, A.Y. 2019. Green-blue water accounting in a soil water balance. AdWR 129: 112-117.

Hoekstra, A.Y., A.K. Chapagain, M.M. Aldaya, and M.M. Mekonnen. 2011. The Water Footprint Assessment Manual: Setting the Global Standard. London, UK: Earthscan.

Hoekstra, A.Y., M.M. Mekonnen, A.K. Chapagain, R.E. Mathews, and B.D. Richter. 2012. Global monthly water scarcity: Blue water footprints versus blue water availability. PLOS ONE 7: 32688.

Hogeboom, R.J., L. Knook, and A.Y. Hoekstra. 2018. The blue water footprint of the world's artificial reservoirs for hydroelectricity, irrigation, residential and industrial water supply, flood protection, fishing and recreation. AdWR 113: 285-294.

Hu, H.H., and L.Z. Xiong. 2014. Genetic engineering and breeding of drought-resistant crops. Annual Review of Plant Biology 65: $715-741$.

IMAJ. 2019. Iran's Ministry of Agriculture Jihad. http://www.maj.ir IWRMC. 2020. Iran's Water Resource Management Company. http:// www.wrm.ir/.

Jägermeyr, J., D. Gerten, J. Heinke, S. Schaphoff, M. Kummu, and W. Lucht. 2015. Water savings potentials of irrigation systems: global simulation of processes and linkages. HESS 19: 3073-3091.

Karandish, F. 2016. Improved soil-plant water dynamics and economic water use efficiency in a maize field under locally water stress. Archives of Agronomy and Soil Science 62: 1311-1323.

Karandish, F., and A.Y. Hoekstra. 2017. Informing national food and water security policy through water footprint assessment: The case of Iran. Water-Sui 9: 831.

Karandish, F., A.Y. Hoekstra, and R.J. Hogeboom. 2018. Groundwater saving and quality improvement by reducing water footprints of crops to benchmarks levels. AdWR 121: 480-491.

Karandish, F., A.Y. Hoekstra, and R.J. Hogeboom. 2020. Reducing food waste and changing cropping patterns to reduce water consumption and pollution in cereal production in Iran. Journal of Hydrology 586: 124881. https://doi.org/10.1016/j.jhydrol. 2020.124881.

Karandish, F., R.J. Hogeboom, and A.Y. Hoekstra. 2021. Physical versus virtual water transfers to overcome local water shortages: A comparative analysis of impacts. Advances in Water Resources. https://doi.org/10.1016/j.advwatres.2020.103811.

Karandish, F., M. Kalanaki, and S.F. Saberali. 2017. Projected impacts of global warming on cropping calendar and water requirement of maize in a humid climate. Archives of Agronomy and Soil Science 63: 1-13.

Karandish, F., and J. Šimůnek. 2018. An application of the water footprint assessment to optimize production of crops irrigated with saline water: A scenario assessment with HYDRUS. Agricultural Water Management 208: 67-82.
Karandish, F., and J. Šimůnek. 2019. A comparison of the HYDRUS (2D/3D) and SALTMED models to investigate the influence of various water-saving irrigation strategies on the maize water footprint. Agricultural Water Management 213: 809-820.

Khazaei, B., S. Khatami, S.H. Alemohammad, L. Rashidi, C. Wu, K. Madani, Z. Kalantari, G. Destouni, et al. 2019. Climatic or regionally induced by humans? Tracing hydro-climatic and landuse changes to better understand the Lake Urmia tragedy. Journal of Hydrology 569: 203-217.

Kinnunen, P., J.H.A. Guillaume, M. Taka, P. D’Odorico, S. Siebert, M. Puma, M. Jalava, and M. Kummu. 2020. Local food crop production can fulfil demand for less than one-third of the population. Nature Food 1: 229-237.

Lin, B.B. 2011. Resilience in agriculture through crop diversification: Adaptive management for environmental change. BioScience 61: 183-193.

Liu, Y., M.S. Gao, W. Wu, S.K. Tanveer, X.X. Wen, and Y.C. Liao. 2013. The effects of conservation tillage practices on the soil water-holding capacity of a non-irrigated apple orchard in the Loess Plateau, China. Soil and Tillage Research 130: 7-12.

Madani, K. 2014. Water management in Iran: What is causing the looming crisis? Journal of Environmental Studies and Sciences 4: $315-328$.

Madani, K., A. AghaKouchak, and A. Mirchi. 2016. Iran's socioeconomic Drought: Challenges of a water-bankrupt nation. Iranian Studies 49: 997-1016.

Madani, K., and S. Khatami. 2015. Water for Energy: Inconsistent Assessment Standards and Inability to Judge Properly. Current Sustainable/Renewable Energy Reports 2: 10-16.

Maghrebi, M., R. Noori, R. Bhattarai, Z. Mundher Yaseen, Q. Tang, N. Al-Ansari, A. Danandeh-Mehr, A. Karbassi, J. Omidvar, H. Farnoush, A. Torabi-Haghighi, B. Klove, and K. Madani. 2020. Iran's agriculture in the anthropocene. Earth's Future 8: 2020EF001547. https://doi.org/10.1029/2020EF001547.

Mekonnen, M.M., and A.Y. Hoekstra. 2012. The blue water footprint of electricity from hydropower. HESS 16: 179-187.

Mekonnen, M.M., and A.Y. Hoekstra. 2016. Four billion people facing severe water scarcity. Science Advances 2: e1500323.

Miller, V.S., and M.A. Naeth. 2019. Hydrogel and organic amendments to increase water retention in anthroposols for land reclamation. Applied and Environmental Soil Science 2019: $1-11$.

Mirchi, A., and A. Madani. 2016. A grand but faulty vision for Iran's water problems. The Guardian. https://www.theguardian.com/ world/2016/may/09/iran-desalination-water

Mirzaei, A., B. Saghafian, A. Mirchi, and K. Madani. 2019. The groundwater-energy-food nexus in Iran's agricultural sector: Implications for water security. Water 11: 1835. https://doi.org/ 10.3390/w11091835.

Moshir Panahi, D., Z. Kalantari, N. Ghajarnia, S. Seifollahi-Aghmiuni, and G. Destouni. 2020. Variability and change in the hydroclimate and water resources of Iran over a recent 30-year period. Scientific Reports 10: 7450. https://doi.org/10.1038/s41598-02064089-y.

Mueller, N.D., J.S. Gerber, M. Johnston, D.K. Ray, N. Ramankutty, and J.A. Foley. 2012. Closing yield gaps through nutrient and water management. Nature 490: 254-257.

Nazari, B., A. Liaghat, M.R. Akbari, and M. Keshavarz. 2018. Irrigation water management in Iran: Implications for water use efficiency improvement. Agricultural Water Management 208: $7-18$.

Nouri, H., B. Stokvis, A. Galindo, and A.Y. Hoekstra. 2019. Water scarcity alleviation through water footprint reduction in agriculture: The effect of soil mulching and drip irrigation. Science of the Total Environments 653: 241-252. 
Oki, T., Y. Agata, S. Kanae, T. Saruhashi, D.W. Yang, and K. Musiake. 2001. Global assessment of current water resources using total runoff integrating pathways. Hydrological Sciences Journal 46: 983-995.

Phalan, B., A. Balmford, R.E. Green, and J.P.W. Scharlemann. 2011. Minimising the harm to biodiversity of producing more food globally. Food Policy 36: S62-S71.

Pi, X.M., T.X. Zhang, B.H. Sun, Q.H. Cui, Y. Guo, M.X. Gao, H. Feng, and D.W. Hopkins. 2017. Effects of mulching for water conservation on soil carbon, nitrogen and biological properties. Frontiers of Agricultural Science and Engineering 4: 146-154.

Postel, S., P. Polak, F. Gonzales, and J. Keller. 2001. Drip irrigation for small farmers-A new initiative to alleviate hunger and poverty. Water International 26: 3-13.

Pretty, J., C. Toulmin, and S. Williams. 2011. Sustainable intensification in African agriculture. International Journal of Agricultural Sustainability 9: 5-24.

Read, L., K. Madani, and B. Inanloo. 2014. Optimality versus stability in water resource allocation. Journal of Environmental Management 133: 343-354.

Richter, B.D., M.M. Davis, C. Apse, and C. Konrad. 2012. A presumptive standard for environmental flow protection. River Research and Applications 28: 1312-1321.

Rosa, L., D.D. Chiarelli, M.C. Rulli, J.D. Angelo, and P. D'Odorico. 2020. Global agricultural economic water scarcity. Science Advances 6: eaaz6031.

Rosa, L., M.C. Rulli, K.F. Davis, D.D. Chiarelli, C. Passera, and P. D'Odorico. 2018. Closing the yield gap while ensuring water sustainability. Environ Res Lett 13: 104002.

SCI. Statistical Center of Iran, Tehran, Iran. 2016. http://www.amar. org.ir.

Sinclair, T.R., and T.W. Rufty. 2012. Nitrogen and water resources commonly limit crop yield increases, not necessarily plant genetics. Global Food Security-Agriculture 1: 94-98.

Steduto, P., T.C. Hsiao, D. Raes, and E. Fereres. 2009. AquaCrop-the FAO crop model to simulate yield response to water: I. Concepts and underlying principles. Agronomy Journal 101: 426-437.

Steduto, P., D. Raes, T.C., Hsiao, and E. Fereres. 2012. AquaCrop: Concepts, rationale and operation. In Crop Yield Response to Water, FAO Irrigation and Drainage, Steduto, P., T.C. Hsiao, E. Fereres, D. Raes, editors, Paper No. 66. Food and Agriculture Organization of the United Nations, Rome, Italy. pp. 17-49.
Steffen, W., K. Richardson, J. Rockstrom, S.E. Cornell, I. Fetzer, E.M. Bennett, R. Biggs, S.R. Carpenter, et al. 2015. Planetary boundaries: Guiding human development on a changing planet. Science 347: 1259855.

UN. 2020. The United Nations Dataset. https://www.un.org/en/ databases.

Vörösmarty, C.J., P. Green, J. Salisbury, and R.B. Lammers. 2000. Global water resources: Vulnerability from climate change and population growth. Science 289: 284-288.

WorldBank., 2020. The World Bank Open Data. https://data. worldbank.org.

Zhuo, L., A.Y. Hoekstra, P.T. Wu, and X.N. Zhao. 2019. Monthly blue water footprint caps in a river basin to achieve sustainable water consumption: The role of reservoirs. Science of the Total Environment 650: 891-899.

Zhuo, L., M.M. Mekonnen, and A.Y. Hoekstra. 2016. Benchmark levels for the consumptive water footprint of crop production for different environmental conditions: A case study for winter wheat in China. Hydrology and Earth System Sciences 20: 4547-4559.

Zhuo, L., M.M. Mekonnen, and A.Y. Hoekstra. 2014. Sensitivity and uncertainty in crop water footprint accounting: a case study for the Yellow River basin. HESS 18: 2219-2234.

Publisher's Note Springer Nature remains neutral with regard to jurisdictional claims in published maps and institutional affiliations.

\section{AUTHOR BIOGRAPHY}

Fatemeh Karandish $(\bowtie)$ has more than 15 years experience in industry and academia as consultant and research scientist in water management and agriculture. Being a professional member of the Water Footprint Network, she focuses mainly on the water-food-energy nexus topics in her researches.

Address: Water Engineering Department, University of Zabol, Zabol, Iran.

Address: Multidisciplinary Water Management, Faculty of Engineering Technology, University of Twente, P.O. Box 217, 7500 AE Enschede, the Netherlands.

e-mail: f.karandish@utwente.nl; f.karandish@uoz.ac.ir; Karandish_h @yahoo.com 